\title{
Unit Shift Dalam Novel The Sea Of Monsters
}

\author{
Lia Nurmalia ${ }^{1}$, Danang Dwi Harmoko ${ }^{2}$, Prapti Wigati Purwaningrum ${ }^{3}$ \\ ${ }^{1,2,3}$ Universitas Bina Sarana Informatika \\ e-mail: ${ }^{1}$ lia.lnm@bsi.ac.id, ${ }^{2}$ danang.dnd@bsi.ac.id, ${ }^{3}$ prapti.pwp@ bsi.ac.id

\begin{tabular}{ccc}
\hline Diterima & Direvisi & Disetujui \\
$16-01-2021$ & $14-02-2021$ & $23-02-2021$ \\
\hline
\end{tabular}

\begin{abstract}
The objectives of the research are to know the translation shift and the translation equivalence in The Sea of Monsters novel which is translated into "Laut Para Monster". This research uses qualitative method through content analysis approach. The writers compared the source text (ST) and the target text (TT) then, did the analysis by using theories proposed by (Catford,1965) and (Nida,1982). The results showed that the largest shifting was the unit level at $65 \%$, followed by intra-system 17\%, structure 15\%, and grade 5\%. For equivalence achieved the majority of formal equivalents, reaching $77 \%$ and dynamic equivalents reached $23 \%$. Those results show that TSu is well transferred into TSa in term of form and content. It can be seen from the translation shift which only happen at the word level, it seems that the translator is faithful to source text, while seen by the translation equivalence, seems that the writer is also faithful to target text.
\end{abstract}

Keywords: shifting, equivalent, novel

Abstrak - Tujuan dari penelitian ini adalah untuk mengetahui pergeseran terjemahan dan persamaan terjemahan dalam novel The Sea of Monsters yang diterjemahkan menjadi "Laut Para Monster". Penelitian ini menggunakan metode kualitatif melalui pendekatan analisis isi. Penulis membandingkan teks sumber (Tsu) dan teks sasaran (Tsa) kemudian, melakukan analisis dengan menggunakan teori-teori yang dikemukakan oleh (Catford, 1965) dan (Nida, 1982). Hasil penelitian menunjukkan bahwa shifting terbesar adalah tataran unit sebanyak $65 \%$, diikuti oleh intra-sistem 17\%, struktur 15\%, dan kelas 5\%. Untuk kesepadanan yang tercapai sebagaian besar adalah kesepadanan formal, mencapai $77 \%$ dan kesepadanan dinamis mencapai $23 \%$. Hasil tersebut menunjukkan bahwa TSu tertransfer dengan baik ke dalam TSa baik dari segi bentuk maupun isi. Hal ini terlihat dari pergeseran terjemahan yang hanya terjadi pada tataran kata, penerjemah terlihat setia pada teks sumber, sedangkan dilihat dari kesamaan terjemahannya, tampaknya penulis juga setia pada teks sasaran.

Kata kunci: pergeseran, kesepadanan, novel

\section{PENDAHULUAN}

Penerjamahan merupakan proses alih bahasa dari teks sumber ke teks sasaran. Dalam prosesnya, untuk menghasilkan sebuah terjemahan yang baik diperlukan pertimbangan dari banyak aspek seperti perbedaan norma dan budaya. Oleh karena itu, diperlukan berbagai penyesuaikan salah satunya yang dikenal dengan istilah shifting.

Shifting merupakan salah satu teknik penerjemahan dimana adanya perubahan kecil dalam tataran linguistik yang terjadi antara bahasa sumber (BSu) ke bahasa sasaran (BSa) (Basil Hatim, 2019). Perubahan linguistik ini pasti terjadi dalam penerjemahan, karena tidak ada bahasa yang sama(Nida, 1982). Untuk mengatasi perbedaan tersebut, penerjemah harus menemukan padanan antara BSu dan BSa baik dari segi bentuk maupun makna, maka teknik shifting menjadi solusi untuk menyelesaikan perbedaan bentuk dalam teks sumber (TSu) dan teks sasaran (TSa) (Munday, 2016).

Penelitian ini untuk mengkaji category shift dimana ada 4 kategori menurut Catford dalam (Fathurrohman, 2017) yaitu Structure Shift, Class Shift, Unit Shift, dan Intra-System Shift. Kajian ini dilakukan pada novel The Sea of Monsters yang diterjemahkan menjadi Laut para Monster. Novel ini dipilih karena peneliti merasa mudah memahamin baik TSu maupun TSa nya. Kemudahan tersebut tentu ada kaitannya dengan teknik penerjemahan yang digunakan penerjemah.

Pergeseran level adalah pergeseran dari tata bahasa ke leksis. Artinya, unit tata bahasa dalam satu bahasa, seperti tenses referensi waktu, makna pasif dalam kalimat. Memiliki unit leksikal dalam bahasa lain sebagai padanan terjemahannya. Misalnya, Siska has stopped crying dan terjemahannya Siska sudah berhenti menangis. Bentuk "telah... ed" dalam bentuk gramatikal "punya + Vb3" sebagai satu kesatuan dalam tata bahasa Inggris yang menunjukkan perfective diterjemahkan ke dalam bahasa Indonesia dengan lexis "sudah".

Pergeseran kategori adalah penyimpangan 
dari korespondensi formal dalam terjemahan. Korespondensi formal adalah setiap kategori tata bahasa dalam bahasa sasaran yang dapat dikatakan menempati posisi yang sama dalam sistem bahasa sasaran sebagai kategori bahasa sumber yang diberikan dalam sistem bahasa sumber. Pergeseran kategori meliputi pergeseran struktur, pergeseran kelas, pergeseran unit, dan pergeseran intra-sistem

Pergeseran yang terjadi dalam penerjemahan dapat mengubah konsep asli teks (Nida, 1982). Hal ini terjadi karena perbedaan struktur gramatikal Bsu dan Bsa sering mengakibatkan beberapa perubahan pada konten informasi atau makna pesan. Derajat kesepadanan makna dalam penerjemahan selanjutnya dapat dikategorikan menjadi dua jenis, yaitu: padanan makna yang terdiri dari makna yang sepenuhnya setara (atau makna lengkap), peningkatan makna, dan makna yang berkurang, dan makna nonekuivalen yang terdiri dari makna yang sepenuhnya berbeda. dan tidak ada artinya (tidak ada ekspresi yang disadari).

Peneliti ingin mengetahui jenis shifting yang banyak dilakukan penerjemah sehingga mampu menyajikan terjemahan yang mudah dipahami oleh pembaca. Serta kaitannya dengan kesepadanan yang dicapai dalam penerjemahan. Kesepadanan dalam penerjemahan ada dua jenis seperti yang diproposisikan oleh (Nida, 1982) yaitu kesepadanan formal dan kesepadanan dinamis.

Dalam (Sipayung, 2018) menurut Catford ada dua jenis pergeseran yakni level shift dan category shift. Ia mengungkapkan bahwa ada empat jenis category shift yaitu structure shift, unit shift, class shift, and intra-system shift. Newmark juga turut memproposisikan tentang pergeseran ia berpendapat bahwa shifting merupakan salah satu prosedur penerjemahan yang melibatkan adanya pergeseran antara TSu dan TSa. Sedangkan Munday berpendpat bahwa shifting dapat terjadi ketika dalam tataran kecil itupun bersifat opsional, dapat dilakukan atau tidak oleh penerjemah.

Dalam (Herlambang, 2017) Nida mengutarakan terdapat dua jenis kesepadanan yaitu kesepadana formal dan kesepadanan dinamis. Kesepadanan formal fokus utamanya adalah bahasa sumber baik dari segi bentuk maupun isi pesan, sedangkan kesepadanan dinamis mengutamakan pesan agar tersampaikan secara sepadan kepada pembaca sasaran, sehingga dalam kesepadanan dinamis bentuk TSu menjadi fokus ke dua.

\section{METODE PENELITIAN}

Penelitian ini menggunakan metode kualitatif berupa analisis isi dari dua subjek penelitian yaitu The Sea of Monsters sebagai (TSu) dan Laut Para Monster sebagai (TSa). Peneliti fokus pada kata, frasa, dan kalimat yang mengalami translation shift dalam novel tersebut. Sampel data yang diambil sebanyak 100 berupa kata, frasa, dan kalimat. Data diambil dengan cara take notes dan studi pustaka, Pateda dalam (Saraswati, 2019) dimana peneliti membaca dan memilih kata, frasa, dan kalimat yang diterjemahkan dengan teknik shifting. Setelah itu peneliti menganalisis data tersebut berdasarkan teori category shift yang diproposisikan oleh Catford lalu mengorelasikan dengan kesepadanan penerjemahan yang dicapai dengan menggunakan teori Nida.

\section{PEMBAHASAN}

\section{Analisis Shifting}

Hasil analisis menunjukan sebagian besar shifting yang ditemukan dalam novel The Sea of Monsters adalah Unit shift $65 \%$, diikuti oleh intrasystem shift $15 \%$, structure shift $15 \%$, dan class shift $5 \%$.

Tabel 1

Analisis translation shift

\begin{tabular}{cccc}
\hline No & Category Shift & Jumlah & Presentase \\
\hline 1 & Unit Shift & 65 & $65 \%$ \\
\hline 2 & Intra-system Shift & 15 & $15 \%$ \\
\hline 3 & Structure Shift & 15 & $15 \%$ \\
\hline 4 & Class Shift & 5 & $5 \%$ \\
\hline & Total & 100 & $100 \%$ \\
\hline
\end{tabular}

Tabel 1 akan dijelaskan secara rinci berikut ini; pembahasan pertama mengenai unit shift.

\section{a. Unit shift}

Unit shift terjadi dimana adanya perbedaan unit bahasa seperti (kata, klausa, frasa, dan kalimat) antara TSu dan TSa dalam penerjemahan (Catford, 1965). Dalam penelitian ini ditemukan unit shift yang berupa pergeseran kata menjadi frasa dan frasa menjadi kata. Berikut contoh kasus dan penjelasannya:

\section{Kata-frasa}

Contoh pertama:

TSu: My nightmare started like this.

TSa: Mimpi buruk ku berawal seperti ini.

Kata yang digarisbawahi dalam TSu diterjemahkan menjadi frasa dalam TSa, kasus tersebut merupakan kasus unit shift yang terjadi dari kata menjadi frasa 
(kata-frasa).

Contoh ke 2:

TSu: She twisted her dishrag.

TSa: Ibu memuntir lap piringnya.

Kata dishrag diterjemahkan menjadi frasa lap piring. Kasus ini menunjukan unit shifting terjadi dari kata menjadi frasa.

\section{Frasa-kata}

Contoh pertama

TSu: It was the middle of the night.

TSa: Saat itu tepat tengah malam.

Frasa yang digarisbawahi dalam TSu diterjemahkan menjadi kata dalam TSa. Kasus tersebut merupakan unit shift yang terjadi dari frasa the middle menjadi kata tengah. (frasa-kata).

Contoh ke 2

TSu: "Ah, dear, about that ... I got a message from Chiron last night."

TSa: “Ah, Sayang, tentang itu ... Ibu mendapat pesan dari Chiron semalam."

Frasa last night dalam TSu diterjemahkan menjadi kata semalam dalam TSa. Kasus tersebut disebut unit shifting yang terjadi dari frasa menjadi kata (frasa-kata).

\section{b. Structure Shift}

Structure shift terjadi ketika adanya perbedaan susunan gramatikal antara TSu dan TSa (Catford, 1965).

1. Susunan struktur kalimat

Contoh pertama

TSu: I was standing on a deserted street

TSa: Aku sedang berdiri di jalanan sunyi

Susunan kalimat TSu menunjukan gramatikal untuk waktu yang sedang berlangsung (subjek+to be+verba+ing) sedangkan dalam TSa disepadankan dengan kata "sedang". Hal ini terjadi karena dalam TSa tidak ada susunan gramatikal tertentu untuk menjukan kegiatan pada waktu tertentu.

2. To-be tidak diterjemahkan

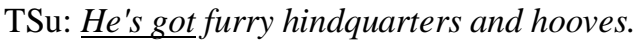

TSa: Dia memiliki bokong berbulu dan sepasang kaki berkuku belah.

Susunan kalimat pada TSu (subjek+tobe+verba) sedangkan dalam TSa (subjek+predikat). Hal ini terjadi karena dalam TSa tidak ada elemen tobe, sehingga pada kalimat ini tobe tidak diterjemahkan.

3. Auxiliary menjadi di depan kalimat

Contoh pertama

TSu: I hadn't used Riptide for so long...

TSa: Sudah lama aku tak menggunakan Riptide .

Pada susunan kalimat TSu kata "had" menunjukan kegiatan yang sudah selesai dan frasa so long merupakan adverbia, dalam TSa diterjemahakn menjadi "sudah lama". Dari kasus ini dapat ditarik kesimpulan bahwa dalam TSa kata had dipadankan dengan "sudah" dan jika pada akhir kalimat terdapat frasa so long maka dapat diterjemahakan dengan cara menggabung keduanya lalu diletakan didepan.

4. To-be menjadi "adalah"

Contoh pertama

TSu: "Grover is a big satyr now...."

TSa: "Grover adalah satir yang sudah dewasa sekarang....."

Pada contoh kasus diatas to-be diterjemahkan menjadi adalah. Hal ini terjadi karena dalam TSa tidak ada elemen tobe dan dalam TSu tidak ada kata yang memiliki arti "adalah".

\section{c. Intra-system Shift}

Intra-system shift terjadi dapa kasus dimana sistem dalam BSu dan BSa berbeda seperti kasus jamak dalam bahasa inggris yang ditandai dengan penambahan 's' sedangkan dalam bahasa Indonesia ditandai dengan mengulang kata tersebut. Berikut contoh kasus yang ditemukan;

Contoh pertama

1. Nomina jamak dalam TSu dan TSa

$\mathrm{TSu}$ : Wind and rain ripped at the palm trees along the sidewalk

TSa: Dera angin dan hujan mencabik-cabik deretan pohon-pohon palem sepanjang trotoar

Pada kasus ini kata trees menunjukan nomina jamak ditandai dengan "s" dari asal kata "tree" menjadi "trees" dalam TSa diterjemahkan menjadi "pohonpohon". 
2. Nomina jamak menjadi tunggal

TSu: My mom had made me promise not to use deadly weapons

TSa: Ibuku telah membuatku berjanji untuk tidak menggunakan senjata berbahaya

Pada kasus diatas kata "weapons" (jamak) diterjemahkan "senjata" (tunggal). Dalam bahasa Indonesia beberapa kata tidak dilakukan pengulangan untuk menunjukan jamak.

\section{d. Class Shift}

Class shift dapat terjadi ketika item dalam BSu diterjemahkan kedalam kelas kata yang berbeda dalam TSa. Catford dalam (Fathurrohman, 2017). Berikut contoh kasus yang ditemukan dalam penelitian ini;

1. Susunan struktur frasa nomina

Contoh pertama

TSu: Celebrating special occasions with blue food

TSa: merayakan momen istimewa dengan makanan serba biru.

Pada contoh di atas terdapat perbedaan susunan kata dalam frasa blue food (ajektiva+nomina) sedangkan dalam TSa menjadi makanan serba biru (nomina+ajektiva). Pergeseran ini terjadi karena frasa ajektiva dalam TSu adalah ajektiva diikuti nomina sedangkan dalam TSa adalah nomina diikuti ajektiva.

2. Susunan frasa nomina menggunakan tanda “_“

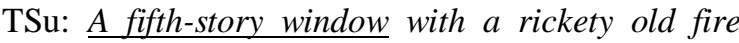
escape

TSa: Jendela lantai lima dengan jalan keluar darurat yang sudah usang dan reyot

Pada frasa yang digarisbawahi tampak bahwa ajektiva dalam TSu menggunakan tanda strip “_“ sedangkan dalam TSa tidak menggunakan strip.

\section{Analisis Kesepadanan}

Setelah dilakukan analisis, dapat disampulkan bahwa sebagian besar kesepadanan yang dicapai adalah kesepadanan formal sebanyak $77 \%$ dan kesepadanan dinamis sebanyak 23\%. Menurut Nida dalam (Bassnett, 2014) bahwa kesepadanan dalam penerjemahan ada dua jenis yaitu kesepadanan formal dan kesepadanan dinamis. Kesepadanan formal fokus pada pesan baik dari segi isi dan bentuk sedangkan kesepadanan dinamis fokus pada pesan agar tersampaikan kepada penerima pesan dengan mengutamakan pembaca sasaran. Berikut tabel analisis kesepadanan.

Tabel 2. Analisis kesepadanan

\begin{tabular}{cccc}
\hline No & Kesepadanan & Jumlah & Presentase \\
\hline 1 & Formal & 77 & $77 \%$ \\
\hline 2 & Dinamis & 23 & $23 \%$ \\
\hline & Total & 100 & $100 \%$ \\
\hline
\end{tabular}

\section{a. Kesepadanan Formal}

Berikut contoh kasus kesepadanan formal yang ditemukan dalam penelitian ini;

1. TSu: I was standing on a deserted street in some little beach town.

TSa: Aku sedang berdiri di jalanan sunyi di sebuah kota pantai kecil.

Pada kalimat diatas bentuk dan isinya tersampaikan. TSu I was standing dipadankan dengan "aku sedang berdiri" dalam TSa. Terlihat dari susunan elemen dalam TSu dan TSa serta isi pesan TSu dapat tersampaikan dengan baik.

2. TSu: But then there was a knock on my bedroom door - my mom called.

TSa: Namun, kemudian ada ketukan di pintu kamar tidurku ibuku Memanggil

Pada contoh (2) susunan kalimat TSu persis dengan TSa serta pesan TSu juga tersampaikan ke dalam TSa. Berdasarkan contoh (2) tampak bahwa penerjemah setia terhadap TSu baik dari segi bentuk maupun pesan. Berikut adalah contoh kasus lainnya yang ditemukan dalam penelitian;

Table 3. Contoh temuan kesepadanan formal 


\begin{tabular}{|c|c|c|c|c|}
\hline No & TSu & $\mathrm{TSa}$ & Kesepadanan & Penjelasan \\
\hline 1. & $\begin{array}{l}\text { I tried not to } \\
\text { think about my } \\
\text { nightmare or } \\
\text { monsters or the } \\
\text { shadow at my } \\
\text { window. }\end{array}$ & $\begin{array}{l}\text { Aku berusaha } \\
\text { tak memikirkan } \\
\text { mimpi burukku } \\
\text { atau monster } \\
\text { atau bayangan } \\
\text { di jendelaku. }\end{array}$ & formal & $\begin{array}{l}\text { Kesepadanan } \\
\text { formal tercapai } \\
\text { karena bentuk TSa } \\
\text { tidak mengalami } \\
\text { pergeseran yang } \\
\text { signifikan dan } \\
\text { maknapun } \\
\text { tersampaikan. }\end{array}$ \\
\hline 2 & $\begin{array}{l}\text { I made a three- } \\
\text { fingered claw } \\
\text { over my heart } \\
\text { and pushed } \\
\text { outward-an } \\
\text { ancient gesture } \\
\text { Grover had } \\
\text { once taught me } \\
\text { for warding off } \\
\text { evil. }\end{array}$ & $\begin{array}{l}\text { Aku membuat } \\
\text { gerakan cakar } \\
\text { tiga-jari di atas } \\
\text { jantungku dan } \\
\text { mendorong ke } \\
\text { depan-isyarat } \\
\text { purbakala yang } \\
\text { pernah } \\
\text { diajarkan } \\
\text { Grover padaku } \\
\text { untuk } \\
\text { menangkal } \\
\text { bala. }\end{array}$ & Formal & $\begin{array}{l}\text { Kesepadanan } \\
\text { formal tercapai } \\
\text { karena bentuk TSu } \\
\text { tersampaikan } \\
\text { dengan baik, } \\
\text { begitupun isinya. }\end{array}$ \\
\hline 3 & $\begin{array}{l}\text { The dream } \\
\text { couldn't have } \\
\text { been real. }\end{array}$ & $\begin{array}{l}\text { Mimpi itu tak } \\
\text { mungkin nyata. }\end{array}$ & Formal & $\begin{array}{l}\text { Kesepadanan } \\
\text { formal tercapai } \\
\text { dengan } \\
\text { menyepadankan } \\
\text { kalimat diatas } \\
\text { dengan baik dari } \\
\text { segi bentuk } \\
\text { maupun isi }\end{array}$ \\
\hline 4 & $\begin{array}{l}\text { For the first } \\
\text { time in my life, } \\
\text { I'd almost made } \\
\text { it an entire year } \\
\text { without getting } \\
\text { expelled }\end{array}$ & $\begin{array}{l}\text { Untuk pertama } \\
\text { kalinya dalam } \\
\text { hidupku, aku } \\
\text { hampir } \\
\text { melewati } \\
\text { setahun penuh } \\
\text { tanpa } \\
\text { dikeluarkan. }\end{array}$ & Formal & $\begin{array}{l}\text { Bentuk TSu } \\
\text { tersampaikan } \\
\text { dalam TSa. Isinya } \\
\text { pun berterima } \\
\text { dalam TSa. }\end{array}$ \\
\hline 5 & $\begin{array}{l}\text { No weird } \\
\text { accidents. }\end{array}$ & $\begin{array}{l}\text { Tak ada } \\
\text { kecelakaan } \\
\text { aneh. }\end{array}$ & Formal & $\begin{array}{l}\text { Kesepadanan } \\
\text { formal tercapai } \\
\text { karena TSu } \\
\text { tersampaikan baik } \\
\text { bentuk maupun } \\
\text { isinya. }\end{array}$ \\
\hline
\end{tabular}

\section{b. Kesepadanan Dinamis}

Kesepadanan dimanis tercapai saat penerjemah fokus terhadap pesan dan pembaca sasaran sehingga terkadang bentuk menjadi fokus ke dua karena yang utama adalah pesan tersampaikan dengan menyesuaikan TSa. Berikut adalah contoh kasus kesepadanan dinamis; 
Table 4. Contoh temuan kesepadanan dinamis

\begin{tabular}{|c|c|c|c|c|}
\hline No & $\mathrm{TSu}$ & $\mathrm{TSa}$ & Kesepadanan & Penjelasan \\
\hline 1 & $\begin{array}{l}\text { As usual, I didn't } \\
\text { have a clue how } \\
\text { wrong I was. }\end{array}$ & $\begin{array}{l}\text { Seperti biasa, aku } \\
\text { tak menyadari } \\
\text { betapa salahnya } \\
\text { aku. }\end{array}$ & Dinamis & $\begin{array}{l}\text { Kesepadanan } \\
\text { dinamis tercapai } \\
\text { karena bentuk } \\
\text { TSu mengalami } \\
\text { pergeseran yang } \\
\text { signifikan pada } \\
\text { bagian “I didn't } \\
\text { have a clue” } \\
\text { menjadi “aku } \\
\text { tak menyadari”. } \\
\text { Namun secara } \\
\text { makna TSa } \\
\text { berterima. }\end{array}$ \\
\hline 2 & $\begin{array}{l}\text { Wind and rain } \\
\text { ripped at the palm } \\
\text { trees along the } \\
\text { sidewalk. }\end{array}$ & $\begin{array}{l}\text { Dera angin dan } \\
\text { hujan mencabik- } \\
\text { cabik deretan } \\
\text { pohon-pohon } \\
\text { palem sepanjang } \\
\text { trotoar }\end{array}$ & Dinamis & $\begin{array}{l}\text { Kesepadanan } \\
\text { dinamis tercapai } \\
\text { karena ada } \\
\text { bagian yang } \\
\text { secara bentuk } \\
\text { mengalami } \\
\text { pergeseran } \\
\text { namun secara } \\
\text { makna tetap } \\
\text { tersampaikan. } \\
\text { Wind menjadi } \\
\text { "dera angin", } \\
\text { ripped menjadi } \\
\text { "mencabik- } \\
\text { cabik". }\end{array}$ \\
\hline 3 & $\begin{array}{l}\text { I turned and saw } \\
\text { my friend Grover } \\
\text { running for his } \\
\text { life. }\end{array}$ & $\begin{array}{l}\text { Aku menoleh dan } \\
\text { melihat temanku } \\
\text { Grover berlari } \\
\text { terbirit-birit. }\end{array}$ & Dinamis & $\begin{array}{l}\text { Kesepadanan } \\
\text { dinamis tercapai } \\
\text { karena bagian } \\
\text { Grover running } \\
\text { for his life } \\
\text { diterjemahkan } \\
\text { menjadi "Grover } \\
\text { berlalri terbirit- } \\
\text { birit". }\end{array}$ \\
\hline 4 & $\begin{array}{l}\text { Yeah, I said } \\
\text { hooves }\end{array}$ & $\begin{array}{l}\text { Betul, aku bilang } \\
\text { derap kaki } \\
\text { hewan. }\end{array}$ & Dinamis & $\begin{array}{l}\text { Kesepadan } \\
\text { an dinamis } \\
\text { tercapai } \\
\text { karena } \\
\end{array}$ \\
\hline
\end{tabular}


Hasil penelitian ini dapat disimpulkan bahwa sebagian besar shifting yang terjadi ada dalam tataran unit sebanyak $65 \%$, diikuti oleh intra-sistem $17 \%$, struktur $15 \%$, dan kelas $5 \%$. Untuk kesepadanan yang tercapai sebagaian besar adalah kesepadanan formal, mencapai $77 \%$ dan kesepadanan dinamis mencapai 23\%. Hasil tersebut menunjukan penerjemah setia terhadap TSu dalam segi bentuk dan segi isi karena terjemahan yang dihasilkan cukup mudah difahami dan nyaman dibaca.

\section{REFERENSI}

Basil Hatim, J. M. (2019). Translation: An advanced resource book for students (2nd ed.). Routledge.

Bassnett, S. (2014). Translation Studies (4th ed.). Routledge.

Fathurrohman, F. I. (2017). Class Shift Translation in English-Indonesian of "Diary of a Wimpy KidCabin Fever" Novel [Syarif Hidayatullah State Islamic University Jakarta]. http://repository.uinjkt.ac.id/dspace/bitstream/1 23456789/38415/1/FAJARIHSAN FATHURROHMAN-FAH.pdf

Herlambang, M. A. K. (2017). a Study of Translation Equivalence and Acceptability on the Subtitle of Intel Advertisements a Study of Translation Equivalence and Acceptability on the Subtitle of Intel [Sanata Dharma University Yogyakarta]. https://repository.usd.ac.id/10994/2/121214085 _full.pdf

Munday, J. (2016). Introducing Translation Studie: Theories and Applications (4th ed.). Routledge.

Nida, E. A. C. R. T. (1982). The theory and practice of translation. Published for the United Bible Societies by E.J. Brill.

Saraswati, A. S. (2019). Analisis Pergeseran Kategori dalam Penerjemahan Bahasa Inggris ke Bahasa Indonesia pada Film Black Swan. Seminar Internasional Kebahasaan Tahun 2019, 409420.

http://badanbahasa.kemdikbud.go.id/lamanbah asa/content/daftar-makalah-subtemapenerjemahan

Sipayung, K. T. (2018). The Impact of Translation Shift and Method on Translation Accuracy Found at Bilingual History Textbook. Humaniora, 30. https://doi.org/https://doi.org/10.22146/jh.2775 